\title{
Lysosomal responses as a sensitive stress index in biomonitoring heavy metal pollution
}

\author{
Francesco Regoli
}

Dipartimento di Biomedicina Sperimentale, Infettiva e Pubblica, Università di Pisa, Via A. Volta 4, I-56100 Pisa, Italy

\begin{abstract}
Lysosomal responses in digestive cells of Mytilus galloprovincialis, collected from a relatively clean area (La Spezia, Italy) and a heavy metal polluted one (Scarlino, Italy), were tested over 1 yr Lysosomal characteristics were also measured in mussels transferred for 6 mo to the polluted site and in mussels from both populations kept for $4 \mathrm{wk}$ in indoor tanks with clean running seawater. Organisms exposed to high environmental levels of heavy metals showed a reduced lysosomal membrane stability and an enhanced production of lipofuscin. Enlarged secondary lysosomes were observed in transplanted mussels. Depuration in clean water caused a slight but significant increase in lysosomal membrane stability of contaminated animals from Scarlino, which, however, remained below the levels observed in the controls. Lipid content in digestive cells of transplanted organisms was lower than in natural mussels from both populations. No evidence of fatty degeneration was observed as a result of heavy metal exposure. These observations confirm the sensitivity of lysosomes to environmental metal pollutants and support the utility of stress indices based on the responses of these organelles in biomonitoring studies.
\end{abstract}

\section{INTRODUCTION}

Marine molluscs are extensively used in biomonitoring studies due to their ability to concentrate both organic and metallic pollutants (Goldberg 1975, 1980 , 1986, Phillips 1980). Recently many authors have outlined the importance of environmental impact assessment programs including methods which measure the biological effects of pollutants on the health condition of organisms (Bayne 1980, Widdows et al. 1981, Bayne et al. 1982, Livingstone 1982, Moore 1985). Many studies have been carried out to develop stress indices at different levels of biological organization (Scott \& Major 1972, Abel 1976, Hrs-Brenko et al. 1977, Widdows 1978, Bayne et al. 1980, Axiak \& George 1987, Axiak et al. 1988, Vega et al. 1989). In fact, these biological responses can be considered as biomarkers of toxicity to central metabolic organs such as the digestive gland of mussels.

Investigations at the subcellular level can reveal alterations at an early stage of response, before integrated cellular damage shifts to the level of organ or whole animal physiological processes. In many instances, the earliest detectable alterations are associated with lysosomes (Moore 1985), a particular class of subcellular organelles mainly involved in the intracellular digestion of food, cellular defence mechanisms, protein and organelles turnover, and regulation of secretory processes. Lysosomal alterations have been reported in several marine invertebrates (i.e. mussels and periwinkles) exposed to xenobiotics such as polycyclic aromatic hydrocarbons (Moore et al. 1980, 1982, 1985 1986, 1987, Lowe et al. 1981, Moore 1982, 1988).

It is known that lysosomes are also involved in the metabolism of heavy metals (Sternlieb \& Goldfischer 1976). Metal sequestration was observed in the lysosomes of mussel tissues by several authors (George et al. 1976, 1978, Moore \& Lowe 1977, Schulz-Baldes 1978, Lowe \& Moore 1979, Harrison \& Berger 1982, Viarengo et al. 1987). As the digestive gland of mussels is a target organ for heavy metal accumulation and its lysosomal system is highly developed (Owen 1972), this organ represents a useful model for investigating the responses of lysosomes to heavy metal pollution along the coastal areas.

However, for correct use of a stress index in the assessment of disturbances due to pollution, it is indispensable to know whether the response investigated exhibits natural fluctuations related, for example, to the seasonal cycle of the animals.

In the present work the lysosomal membrane stability was tested in the digestive gland of 2 populations of 
Mytilus galloprovincialis, from a clean and a heavy metal polluted area respectively, as well as in those maintained in clean running seawater. Lysosomal responses were also assayed in mussels transplanted from the clean to the polluted area.

\section{MATERIALS AND METHODS}

Experimental design. Lysosomal responses were tested at intervals over a period of $1 \mathrm{yr}$ in mussels from 2 different areas of the Tyrrhenian Sea: Scarlino, highly polluted by heavy metals of industrial origin, and La Spezia, where mussels were obtained from a local marine farm.

Lysosomal membrane stability (based on hydrolase latency) was also measured in mussels transplanted for 6 mo from La Spezia to Scarlino and in organisms from both the populations allowed to depurate for $4 \mathrm{wk}$. This part of the work was carried out at the Interuniversitary Centre of Marine Biology (Livorno), where the system included depuration tanks $(13 \times 1 \times 1 \mathrm{~m})$ supplied with running unfiltered seawater at a filow rate of $5 \mathrm{i} \mathrm{s}^{-1}$. Water temperature was approximatively $14{ }^{\circ} \mathrm{C}$ and salinity $37 \%$.

Metal analysis. Digestive glands dissected from 20 specimens ( $5 \pm 1 \mathrm{~cm}$ in shell length), were subdivided in 5 samples, each constituted by the organs of 4 mussels, and stored at $-30{ }^{\circ} \mathrm{C}$ until processed for analysis.

Samples were dry weighed and then digested with nitric acid ( $\mathrm{BDH}$ Aristar $70 \%$ ), first at room temperature for $8 \mathrm{~h}$, then at $120^{\circ} \mathrm{C}$ for $10.5 \mathrm{~h}$ in teflon vessels.

The same procedure was also used for lobster standards (provided by National Research Council, Canada) to check the accuracy of the analytical methods.

$\mathrm{Cu}, \mathrm{Mn}, \mathrm{Fe}, \mathrm{Pb}, \mathrm{Zn}$ were determined by Atomic Absorption Spectrophotometry (IL model S11 equipped with a deuterium background corrector and an IL model 755 graphite furnace).

Lysosomal responses. Small pieces of digestive glands, rapidly excised from 10 mussels, were placed on cork chucks, immersed in hexane precooled to $-70^{\circ} \mathrm{C}$ in liquid nitrogen, sealed by double wrapping in parafilm and stored at $-80^{\circ} \mathrm{C}$.

Lysosomal membrane stability was tested in $10 \mu \mathrm{m}$ unfixed duplicate cryostat sections by determining the lysosome acid labilization period which is the time of pretreatment of serial sections at $\mathrm{pH} 4.5$ and $37^{\circ} \mathrm{C}$ required to artificially labilise the lysosomal membrane. At that time, a substrate of the assayed enzyme can penetrate through the membrane into the lysosomes and react with the lysosomal enzyme. The enzyme-substrate is then made visible by staining with a diazonium salt. When maximum staining intensity is achieved lysosomal stability (in min) can be calculated.
The acid hydrolase $\beta$ - $N$-acetylhexosaminidase was tested according to Moore $(1976,1988)$ as described below.

Sections, cut in a Leitz 1720 cryostat $\left(-27^{\circ} \mathrm{C}\right.$ cabinet temperature and knife packed in dry ice), were pretreated at $37{ }^{\circ} \mathrm{C}$ in $0.1 \mathrm{M}$ citrate buffer ( $\left.\mathrm{pH} 4.5\right)$ containing $2.5 \% \mathrm{NaCl}$ in order to labilize the lysosomal membrane (Bitensky et al. 1973, Moore 1976). Pretreatment times of $0,2,5,10,15,20,25,30 \mathrm{~min}$ were applied to the serial sections. The slides were then incubated for $20 \mathrm{~min}$ at $37^{\circ} \mathrm{C}$ in $50 \mathrm{ml}$ of $0.1 \mathrm{M}$ citrate buffer ( $\mathrm{pH} 4.5$ ), containing $20 \mathrm{mg}$ naphthol AS-BI-N-acetyl- $\beta$-Dglucosaminide (Sigma) previously dissolved in $2.5 \mathrm{ml}$ $\mathrm{N}$-N-dimethylformamide (instead of 2-methoxyethanol as in the original method), $1.5 \mathrm{~g} \mathrm{NaCl}$ and $3.5 \mathrm{~g}$ of Polypep (Sigma), a low viscosity polypeptide acting as a section stabilizer (Bitensky et al. 1973, Moore 1976). Sections rinsed in $3 \% \mathrm{NaCl}$ at $37^{\circ} \mathrm{C}$ for 2 min were then transferred to 0.1 i phosphate buffer (pH 7.5) containing the diazonium coupler Fast Blue RR or Fast Violet $B\left(1 \mathrm{mg} \mathrm{ml}^{-1}\right)$ for $10 \mathrm{~min}$ at room temperature. After a brief rinse in tap water, slides were fixed in $4 \%$ câlciuñ forninol $(+2.5 \% \mathrm{~N}$ aCl) and mounted for micro scopical examination.

The labilization period was determined according to Moore (1988) by microscopical assessment of the pretreatment time required to produce maximal staining intensity in the series of sections.

Cryostat sections were also stained for lipofuscin according to Schmorl (Pearse 1972), and for unsaturated neutral lipids with the Oil Red O reaction (Bancroft 1967).

Statistical analysis. Data were compared using Student's $t$-test for heavy metal concentrations, and MannWhitney $U$-test for lysosomal membrane stability (Moore et al. 1979, Moore 1988).

\section{RESULTS}

Concentrations of $\mathrm{Cu}, \mathrm{Mn}, \mathrm{Fe}$ and $\mathrm{Pb}$ in the digestive gland of mussels were higher at Scarlino than at La Spezia, whereas $\mathrm{Zn}$ did not show significant differences (Table 1).

Lysosomal membrane stability differed considerably $(\mathrm{p}<0.05)$ in mussels from the 2 study sites (Fig. 1). The labilization period of the lysosomal membrane ranged with a few exceptions from 20 to $25 \mathrm{~min}$ in mussels from La Spezia (Fig, 1A), while much lower values (2 to 6 min) were seen in mussels from Scarlino (Fig. 1B).

Mussels transplanted from La Spezia to Scarlino for 1 wk showed a reduction $(p<0.05)$ of the lysosomal membrane stability to levels comparable to those observed in native mussels at Scarlino (Fig. 1C).

No changes were observed in mussels from La 
Table 1. Mytilus galloprovincialis. Heavy metal concentrations in $\mu \mathrm{g} \mathrm{g}^{-1}$ dry weight (mean $\pm S D, n=5$ ) in the digestive gland of mussels from La Spezia and Scarlino. Differences between mean values: ${ }^{\cdot}=p>0.05 ;{ }^{\cdots}=p<0.05$

\begin{tabular}{|cccccc|}
\hline Location & $\mathrm{Cu}$ & $\mathrm{Mn}$ & $\mathrm{Fe}$ & Zn & $\mathrm{Pb}$ \\
\hline La Spezia & $15.6 \pm 0.6$ & $19.1 \pm 5.2$ & $605 \pm 88$ & $118 \pm 17$ & $6.1 \pm 1.3$ \\
Scarlino & $22.2 \pm 1.1$ & $198 \pm 68$ & $3150 \pm 468$ & $153 \pm 26$ & $152 \pm 32$ \\
& $\cdots$ & $\cdots$ & $\cdots$ & & $\cdots$ \\
\hline
\end{tabular}

Spezia during the 4 wk of depuration (Fig. 2A), whereas a slight but significant increase of lysosomal membrane stability $(\mathrm{p}<0.05)$ was observed in mussels
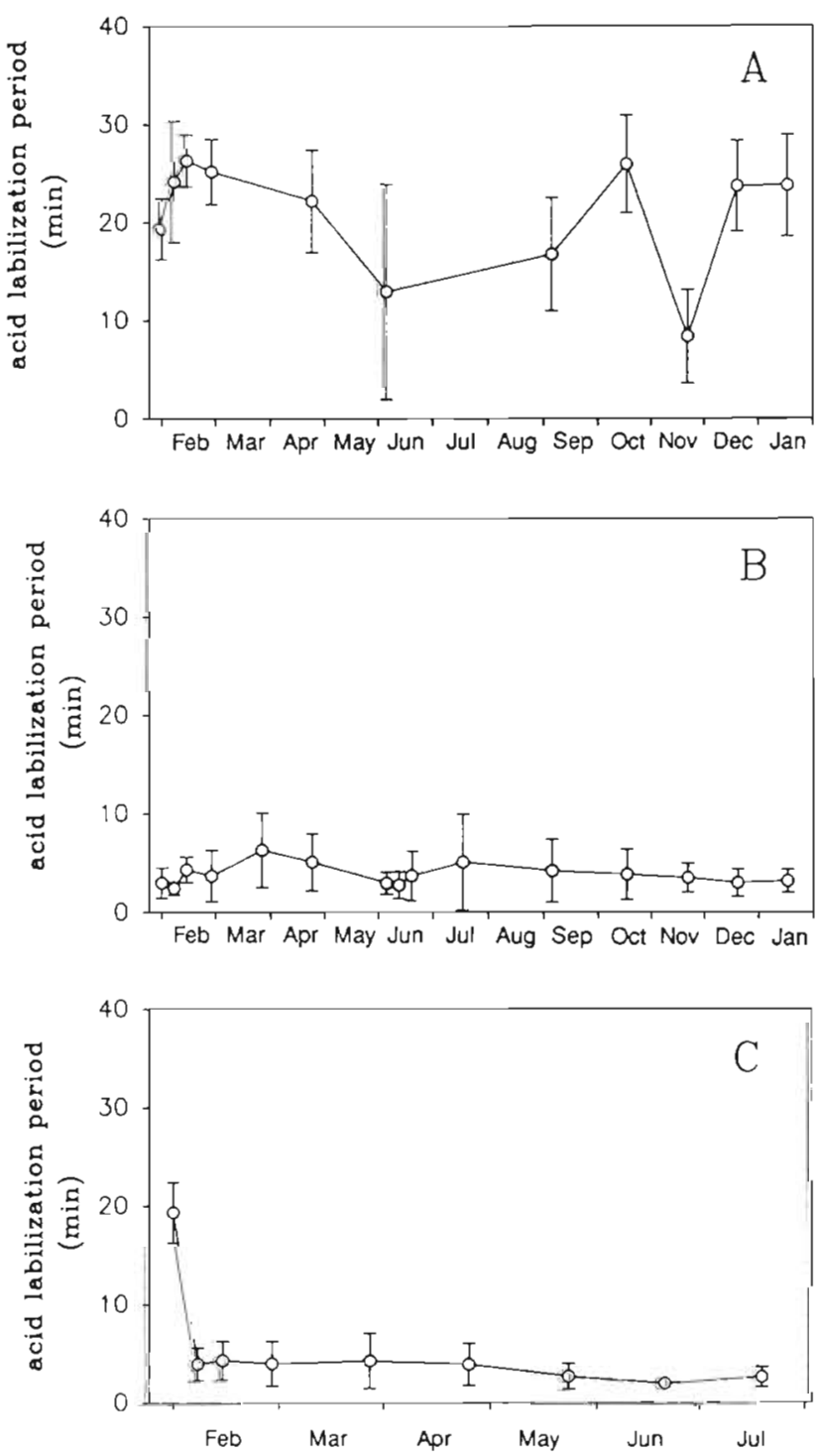

Fig. 1. Mytilus galloprovincialis. Responses of lysosomal membrane stability in digestive gland of (A) mussels from La Spezia, (B) mussels from Scarlino, and (C) mussels from La Spezia transplanted to Scarlino. (Mean $\pm \mathrm{SD}, \mathrm{n}=10$ )
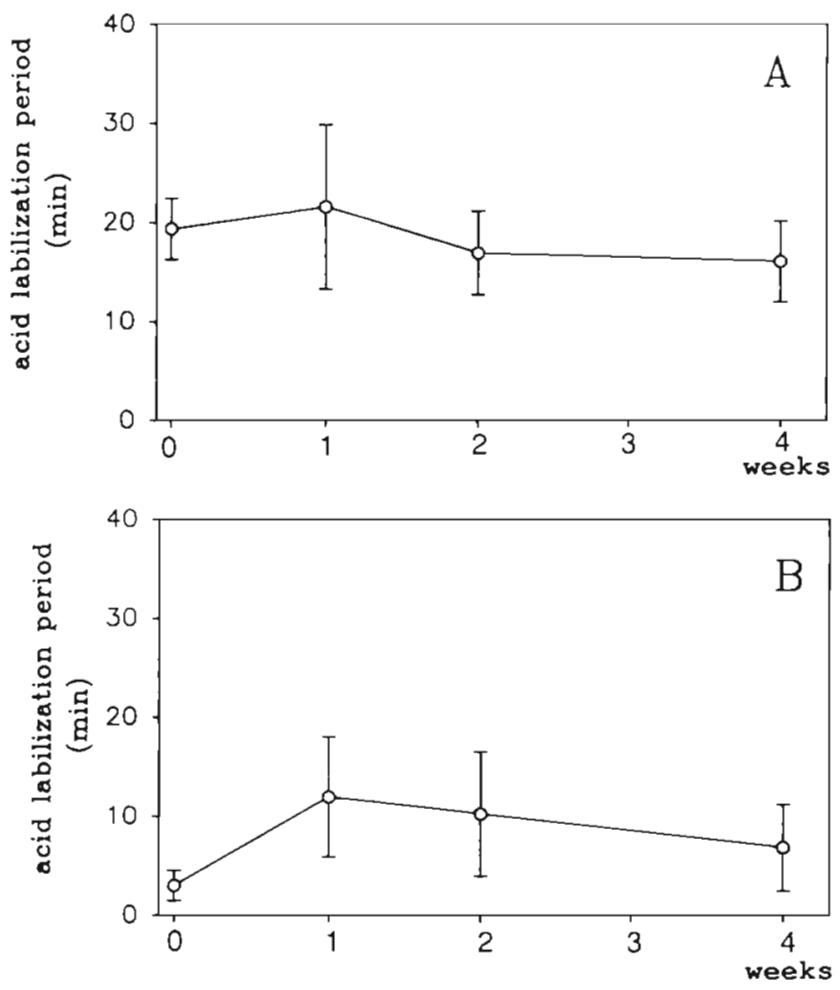

Fig. 2. Mytilus galloprovincialis. Effects of depuration in clean running seawater on lysosomal membrane stability in mussels from (A) La Spezia and (B) Scarlino. (Mean $\pm S D, n=10$ )

from Scarlino (Fig. 2B). However, this increase remained below the level observed in controls.

Lysosomal perturbations in mussels exposed to environmentally high levels of heavy metals was also inferred from evidence of an enhanced amount of lipofuscin in tertiary lysosomes (Fig. 3). In addition, mussels transplanted to Scarlino also developed enlarged secondary lysosomes (Fig. 4).

Seasonal differences in the content of unsaturated neutral lipids were observed in the digestive gland of natural mussels; maximum of staining occurred in summer and minimum in winter and autumn, with similar patterns in the 2 populations. However, mussels transplanted during the winter from La Spezia to Scarlino failed to increase their lipid content, and the maximum summer staining was not observed (Fig. 5). 


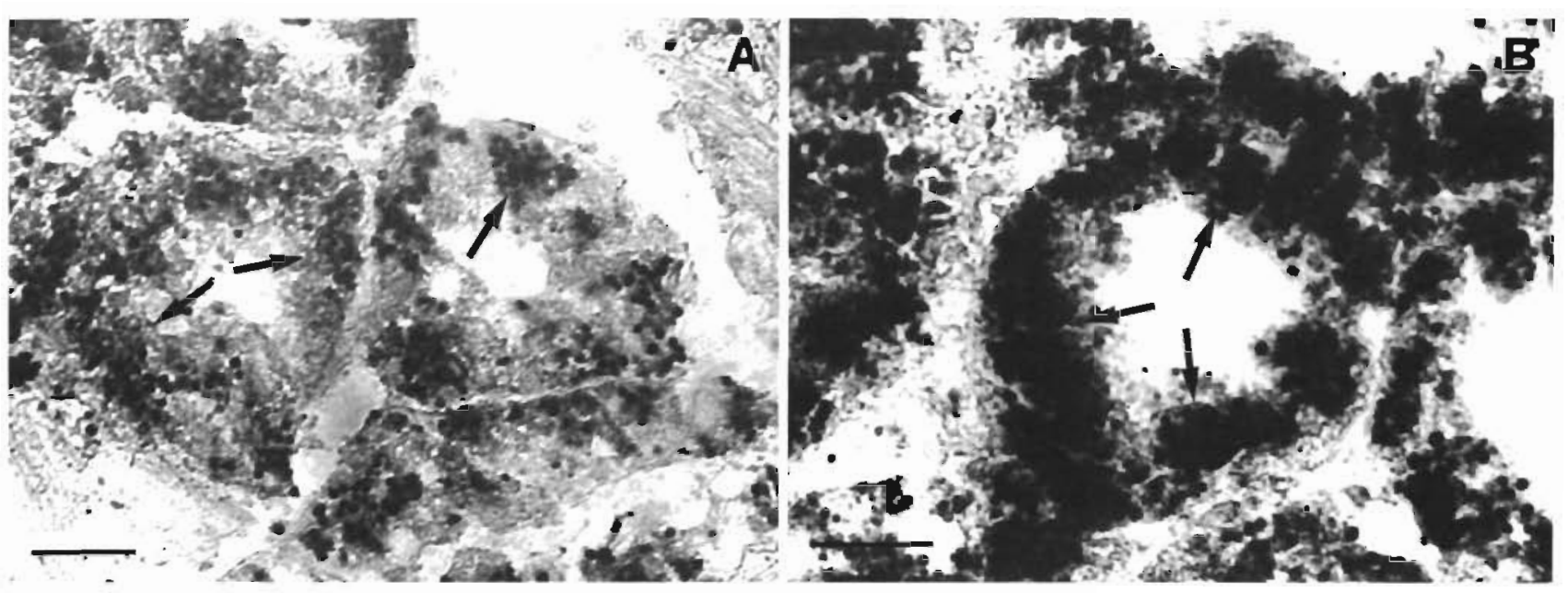

Fig. 3. Mytilus galloprovincialis. Digestive tubules showing lipofuscin accumulation (arrows) in tertiary lysosomes of mussels from (A) La Spezia and (B) Scarlino. Scale bar: $20 \mu \mathrm{m}$
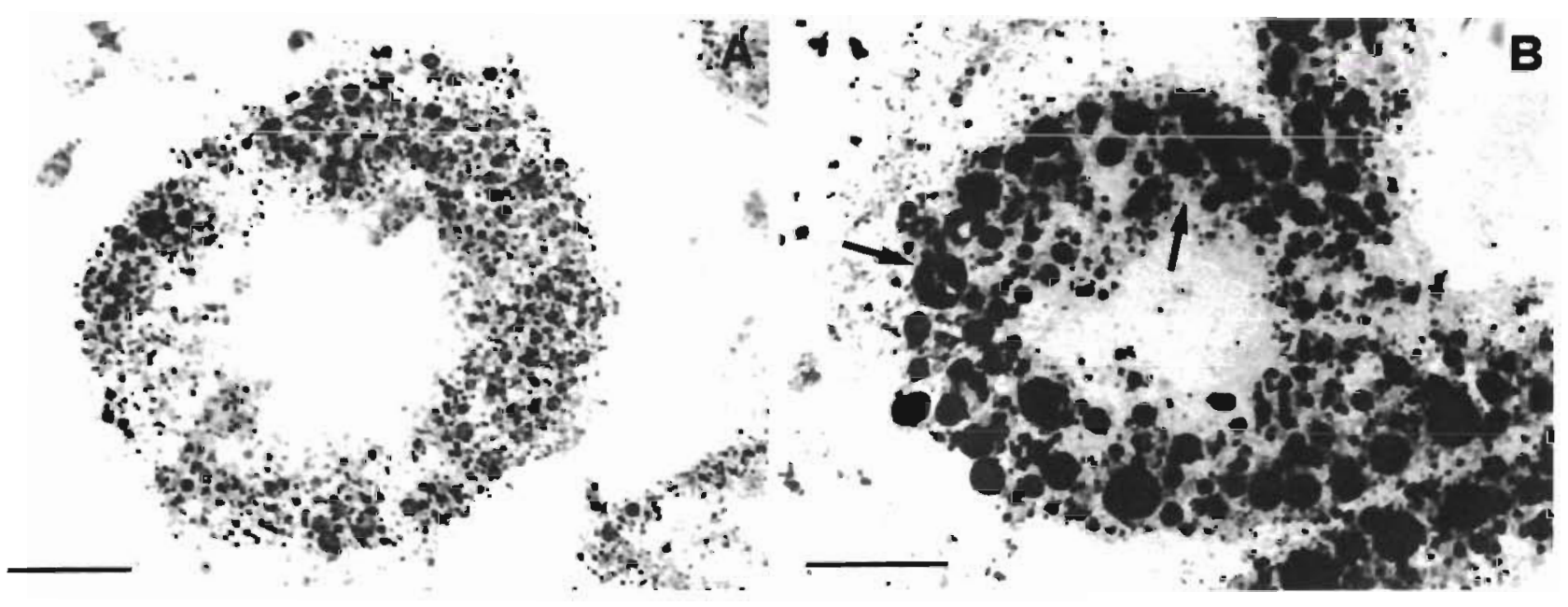

Fig. 4. Mytilus galloprovincialis. Digestive tubules reacted for the lysosomal marker enzyme $\beta$-N-acetylhexosaminidase. (A) Normal lysosomes and (B) enlarged lysosomes (arrows) in mussels from La Spezia transplanted to Scarlino. Scale bar: 20 um

\section{DISCUSSION}

From this study it appears that concentrations of 5 metals $\left(\mathrm{Cu}_{1} \mathrm{Mn}, \mathrm{Fe}_{\mathrm{r}} \mathrm{Zn}\right.$ and $\left.\mathrm{Pb}\right)$ in mussels from La Spezia are similar to values reported for relatively unpolluted areas of the Mediterranean (Lulic \& Strohal 1974, Sheppard \& Bellamy 1974, Fowler \& Oregionj 1976, Majori et al. 1978, Renzoni 1980, Leonzio et al. 1981). On the contrary, mussels from Scarlino were heavily contaminated, especially by lead, iron and manganese. The values presented in this work refer only to February, but similar differences in heavy metal concentrations were observed over the course of $1 \mathrm{yr}$ (author's unpubl. data), and are assumed to be related to the presence in Scarlino of factories which use pyrites and titanium minerals to produce sulphuric acid and titanium dioxide.

The analysis of lysosomal membrane stability in mussels from Scarlino (both natural and transplanted) clearly indicated a severe dysfunction of the lysosomal system. This phenomenon is presumably related to the excessive levels of heavy metals accumulated in the organelles.

Similar alterations were described in marine invertebrates exposed to xenobiotics such as polycyclic aromatic hydrocarbons, polychlorinated biphenyls and heavy metals (Moore \& Stebbing 1976, Moore et al. 1978, Moore 1979, 1988, Harrison \& Berger 1982, Moore \& Clarke 1982, Livingstone et al. 1986, Moore \& Viarengo 1987, Viarengo et al. 1987). 


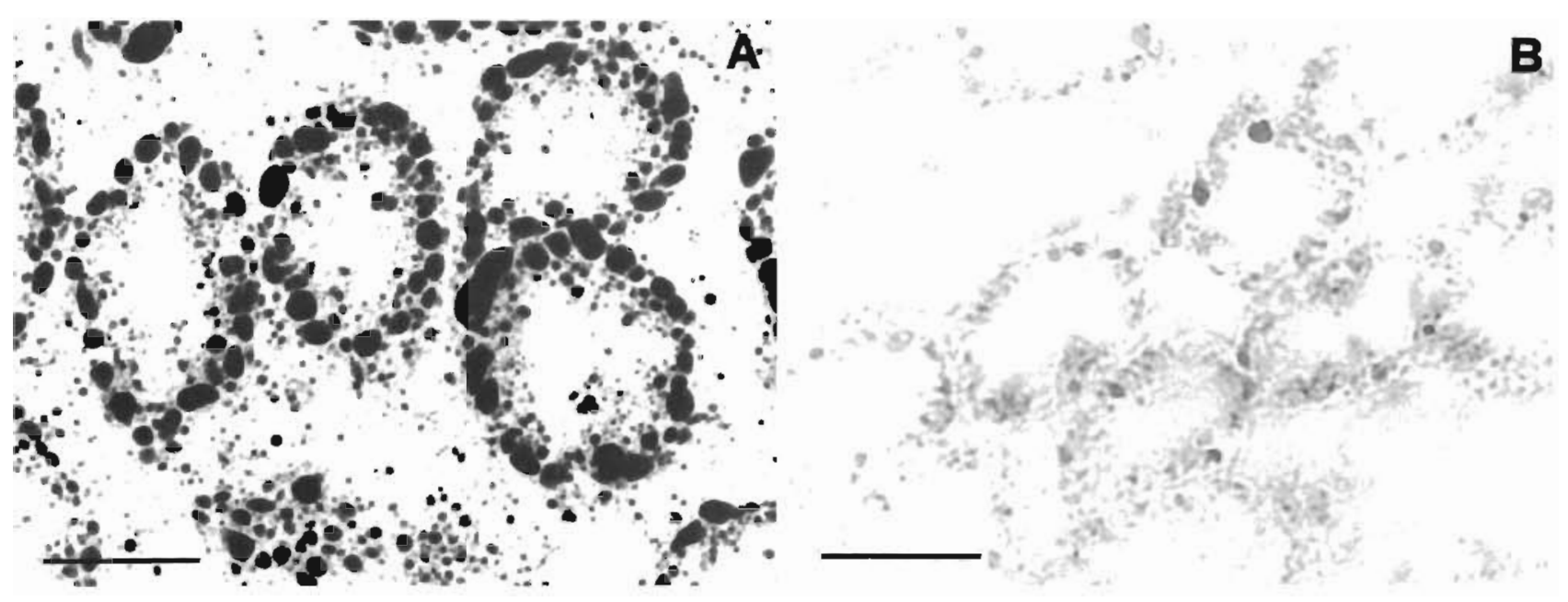

Fig. 5. Mytilus galloprovincialis. Digestive tubules showing lipid content in summer. (A) Natural mussels from Scarlino showing numerous large lipid droplets, which were found also in the mussels of La Spezia. (B) Mussels from La Spezia transplanted to Scarlino showing an important reduction of lipid droplets. Scale bar: $50 \mu \mathrm{m}$

The severe dysfunction of the lysosomal system in mussels from Scarlino, as indicated by the reduction of membrane stability, probably masked any effects resulting from seasonal differences in environmental conditions.

The heterogeneous response in lysosomal membrane stability found in summer in mussels from La Spezia, indicated by the large standard deviation (Fig. 1A), could be due to a thermal stress induced by the increase of temperature in the relatively closed and shallow waters of the marine farm during the summer. In this respect, Moore (1976) observed a significant reduction in the latency of lysosomal $\beta$-hexosaminidase after exposure of mussels to temperatures of 25 to $28^{\circ} \mathrm{C}$. In addition, he found a greater decrease in summer than in winter, a finding which suggests a possible seasonal difference in lysosomal activity. The data presented here support the hypothesis that mussels are more susceptible to stress in summer than in winter.

The reduction in lysosomal membrane stability observed in November (Fig. 1A) could be related to the reproductive cycle. Although Mytilus galloprovincialis in the Mediterranean has a prolonged reproductive period, principal spawning usually occurs in autumn (Berner 1935, Renzoni 1963, Bourcart \& Lubet 1965).

Thompson et al. (1974) demonstrated that in Mytilus edulis metabolic reserves move from digestive gland to gonad during the later stages of gametogenesis and after spawning. These events, associated with a degeneration in the structure of digestive tubules and an increase of autophagic processes, result in severe lysosomal disturbance (Bayne et al. 1978).

More difficult to interpret are the results concerning mussels maintained for $4 \mathrm{wk}$ in indoor depuration tanks. No significant effects were observed in mussels from La Spezia, thus indicating good environmental conditions (such as level of available food) in the experimental system. Mussels from Scarlino showed only a slight increase in lysosomal stability. However, it must be pointed out that only a slight decrease in trace metal concentrations was observed after the depuration period (author's unpubl. data); this fact could explain the persistance of the lysosomal stress.

The presence of enlarged lysosomes in mussels transplanted to Scariino showed another feature of the complex lysosomal response to pollutants; lysosomal enlargment provoked by fusion reflect profound alterations in the rate of fusion events in the lysosomalvacuolar system of the digestive cells (Hawkins 1980, Moore 1985, 1988). In this respect the scarcity of enlarged lysosomes in the natural mussels of Scarlino deserves further investigation.

Lipofuscin is the end product of lipid peroxidation of membraneous components (Davies 1983) and, if accompanied by lysosomal alterations, can be considered a good indicator of increased autophagic processes (Moore 1988). Moreover, lipofuscin granules may contribute to the detoxification of heavy metals which, trapped both chemically and mechanically (George 1983), are eliminated by excretion of residual bodies (Viarengo 1989, Viarengo et al. 1990). The enhanced levels of lipofuscin found in mussels from the polluted environment are in agreement with the data of Viarengo et al. (1987) who observed lipofuscin accumulation in the digestive cells of mussels exposed to $\mathrm{Cu}$.

Furthermore, Moore (1988) reported an accumulation of unsaturated neutral lipids within lysosomes of digestive cells in mussels exposed to organic pollutants. We did not observe a similar effect in mussels exposed to heavy metals in the Scarlino area. Mytilus 
galloprovincialis from both Scarlino and La Spezia showed a marked seasonal cycle with a maximum lipid content in summer and minimum in winter. Thompson et al. (1974) also found lipids stored in the digestive gland of $M$. edulis during the summer, and a total gland lipid decrease during late August and September.

The very low levels of digestive gland lipids in transplanted mussels, with no appreciable increase during the summer, could be explained by the fact that reserve materials from this organ are rapidly utilized during periods of stress (Thompson et al. 1974). The scarcity of energy reserves available for gametogenesis would probably reduce the reproductive capability of these organisms. Therefore, it is suggested that the difference in gland lipid content of transplanted animals as compared with natural mussels from Scarlino may be due to a different adaptation to the stressed environment.

The present work confirms the sensitivity of lysosomes to environmental pollutants including heavy metals. Alterations of these organelles could interfere with the intracellular digestion of food, the normal turnover of proteins and organeiles, and the reguiation of fusion processes associated with the lysosomal-vacuolar system. Lysosomal responses, as early warning system for detection of environmental disturbances, could represent a useful tool for biomonitoring studies. However, for a correct interpretation of the results, seasonal variations, mainly due to the reproductive cycle of mussels, should be considered.

Acknowledgements. We thank Profs. S. Bonotto and E. Orlando for the critical revision of the manuscipt.

\section{LITERATURE CITED}

Abel, P. D. (1976). Effect of some pollutants on the filtration rate of Mytilus. Mar. Pollut. Bull. 7: 228-231

Axiak, V., George, J. J. (1987). Effects of exposure to petroleum hydrocarbons on the gill function and ciliary activities of a marine bivalve. Mar. Biol. 94: 157-162

Axiak, V., George, J. J., Moore, M. N. (1988). Petroleum hydrocarbons in the marine bivalve Venus verrucosa: accumulation and cellular responses. Mar. Biol. 97. $225-230$

Bancroft, J. D. (1967). An introduction to histochemical technique. Butterworths, London

Bayne, B. L. (1980). Physiological measurements of stress Rapp. P.-v. Réun. Cons. perm. int. Explor Mer. 179: 56-61

Bayne, B. L., Brown, D. A. Harrison, F. L., Yevich, P. D. (1980). Mussel health. In: Goldberg, E. D. (ed.) The international mussel watch. National Academy of Sciences, Washington, D.C., p. 163-235

Bayne, B. L., Moore, M. N., Lowe, D. M., Widdows, J. (1978). Further studies on the effects of stress in the adult on eggs of Mytilus edulis. J. mar. biol. Ass. U. K. 58: 825-841

Bayne, B. L., Widdows, J., Moore, M. N., Salked, P., Worrall, C. M., Donkin, P. (1982). Some ecological consequences of the physiological and biochemical effects of petroleum compounds on manne molluscs. Phil. Trans. R. Soc. Lond. (Ser. B) 297: 219-239

Berner, L. (1935). La reproduction des moules comestibles (Mytilus edulis L. et Mytilus galloprovincialis Lmk. ) et leur répartition géographique. Bull. Inst. océanogr. Monaco 680: $1-8$

Bitensky, L., Butcher, R. S., Chayen, J. (1973). Quantitative cytochemistry in the study of lysosomal function. In: Dingle, J. T (ed.) Lysosomes in biology and pathology, Vol. 3. Elsevier, Amsterdam, p. 465-510

Bourcart, C., Lubet, P. (1965). Cycle sexual et évolution des réserves chez Mytilus galloprovincialis Lmk. (Mollusque bivalve). Rapp. Comm. int. Mer médit. 18: 155-158

Davies, I. (1983). Ageing. Edward Arnold, London

Fowler, S. W., Oregioni, B. (1976). Trace metals in mussels from the N. W. Mediterranean. Mar. Pollut. Bull. 7: 26-29

George, S. G. (1983). Heavy metal detoxification in the mussel Mytilus edulis. Composition of Cd-containing kidney granules (tertiary lysosomes). Comp. Biochem. Physiol. $76 \mathrm{C}: 53-57$

George, S. G., Pirie, B. J. S., Cheyne, A. R., Coombs, T L., Grant, P. T (1978). Detoxication of metals by marine bivalves: an ultrastructural study of the compartmentation of copper and zinc in the oyster Ostrea edulis. Mar. Biol. 45: $147-156$

George, S. G., Pirie, B. J. S., Coombs, T L. (1976). The kinetics of accumulation and excretion of ternc nydroxide in Mytilus edulis (L) and its distribution in tissues. J. exp. mar. Biol. Ecol. 23: 78-84

Goldberg, E. D. (1975). The mussel watch - a first step in global marine monitoring. Mar. Pollut. Bull. 6: 111

Goldberg, E. D. (1980). The international mussel watch. National Academy of Sciences, Washington, D.C.

Goldberg, E. D. (1986). The mussel watch concept. Envir Monitor. Assessm. 7: 91-103

Harrison, F. L., Berger, R. (1982). Effects of copper on the latency of lysosomal hexosaminidase in the digestive cells of Mytilus edulis. Mar. Biol. 68: 109-116

Hawkins, H. K. (1980). Reactions of lysosomes to cell injury. In: Trump, B. F., Arstila, A. V (eds.) Pathobiology of cell membranes, Vol. 2. Academic Press, New York, p. 252-285

Hrs-Brenko, M., Claus, C., Bubic', S. (1977). Synergistic effects of lead, salinity and temperature on embryonic development of the mussel Mytilus galloprovincialis. Mar Biol. 44: 109-115

Leonzio, C., Bacci, E., Focardi, S., Renzoni, A. (1981). Heavy metals in organisms from the northern Tyrrhenian Sea. Sci. Total Environ. 20: 131-146

Livingstone, D. R. (1982). General biochemical indices of sublethal stress. Mar Pollut. Bull. 13(8): 261-263

Livingstone, D. R., Moore, M. N., Lowe, D. M., Nasci, C., Farrar, S. V (1986). Responses of the cytochrome P-450 monooxygenase system to diesel oil in the common mussel Mytilus edulis L. and the periwinkle Littorina littorea L. Aquat. Toxicol. 7: 79-91

Lowe, D. M., Moore, M. N. (1979). The cytochemical distributions of zinc ( $\mathrm{Zn} \mathrm{II)} \mathrm{and} \mathrm{iron} \mathrm{(Fe} \mathrm{III)} \mathrm{in} \mathrm{the} \mathrm{common} \mathrm{mussel,}$ Mytilus edulis, and their relationship with lysosomes. J. mar. biol. Ass. U. K. 59: 851-858

Lowe, D. M., Moore, M. N., Clarke, K. R. (1981). Effects of oil on digestive cells in mussels: quantitative alterations in cellular and lysosomal structure. Aquat. Toxicol. 1 213-226

Lulic, S., Strohal, P. (1974). The application of neutron activation analysis in studying the marine pollution processes. Revue int. Océanogr. méd. 33; 119-123 
Majori, L., Nedoclan, G., Modonutti, G. B., Daris, F. (1978). Study of seasonal variations of some trace elements in the tissue of Mytilus galloprovincialis taken in the Gulf of Trieste. Revue int. Océanogr méd. 49: 37-40

Moore, M. N. (1976). Cytochemical demonstration of latency of lysosomal hydrolases in digestive cells of the common mussel, Mytilus edulis, and changes induced by thermal stress. Cell Tissue Res. 175: 279-287

Moore, M. N. (1979). Cellular responses to polycyclic aromatic hydrocarbons and phenobarbital in Mytilus edulis. Mar. environ. Res. 2: 255-263

Moore, M. N. (1982). Lysosomes and environmental stress. Mar Pollut. Bull. 13(2): 42-43

Moore, M. N. (1985). Cellular responses to pollutants. Mar. Pollut. Bull. 16: 134-139

Moore, M. N. (1988). Cytochemical responses of the lysosomal system and NADPH-ferrihemoprotein reductase in molluscan digestive cells to environmental and experimental exposure to xenobiotics. Mar. Ecol. Prog. Ser. 46: 81-89

Moore, M. N., Bubel, A., Lowe, D. M. (1980). Cytology and cytochemistry of the pericardial gland cells of Mytilus edulis and their lysosomal responses to injected horseradish peroxidase and anthracene. J. mar. biol. Ass. U. K. 60: 135-149

Moore, M. N., Clarke, K. R. (1982). Use of microstereology and quantitative cytochemistry to determine the effects of crude oil-derived aromatic hydrocarbons on lysosomal structure and function in a marine bivalve mollusc, Mytilus edulis. Histochem. J. 14: 713-718

Moore, M. N., Lowe, D. M. (1977). The cytology and cytochemistry of the hemocytes of Mytilus edulis and their responses to experimentally injected carbon particles. J. Invertebr. Path. 29: 18-30

Moore, M. N., Lowe, D. M., Fieth, P. E. M. (1978). Lysosomal responses to experimentally injected anthracene in the digestive cells of Mytilus edulis. Mar. Biol. 48: 297-302

Moore, M. N., Lowe, D. M., Livingstone, D. R., Dixon, D. R. (1986). Molecular and cellular indices of pollutant effects and their use in environmental impact assessment. Water Sci. Tech. 18: 223-232

Moore, M. N., Lowe, D. M., Moore, S. L. (1979). Induction of lysosomal destabilisation in marine bivalve molluscs exposed to air. Mar. Biol. Lett. 1: 47-57

Moore, M. N., Mayernick, J. A., Giam, C. S. (1985). Lysosomal responses to a polynuclear aromatic hydrocarbon in a marine snail: effects of exposure to phenanthrene and recovery. Mar environ. Res. 17: 230-233

Moore, M. N., Pipe, R. K., Farrar, S. V (1982). Lysosomal and microsomal responses to environmental factors in Littorina littorea from Sullom Voe. Mar. Pollut. Bull, 13: 340-345

Moore, M. N., Pipe, R. K., Farrar, S. V (1987). Induction of lysosomal lipid accumulation and fatty degeneration by polycyclic aromatic hydrocarbons in molluscan digestive cells. Mar. environ. Res. (Abstract) 24: 352-353

Moore, M. N., Stebbing, A. R. D. (1976). The quantitative

This article was submitted to the editor cytochemical effects of three metal ions on a lysosomal hydrolase of a hydroid. J. mar. biol. Ass. U.K. 56: 995-1005

Moore, M. N., Viarengo, A. (1987). Lysosomal membrane fragility and catabolism of cytosolic proteins: evidence for a direct relationship. Experientia $43: 320-323$

Owen, G. (1972). Lysosomes, peroxisomes and bivalves. Sci. Prog., Oxf. 60: 299-318

Pearse, A. G. E. (1972). Histochemistry, theoretical and applied, Vol. 2. Churchill-Livingstone, London

Phillips, D. J. H. (1980). Quantitative aquatic biological indicators. Applied Science Publishers Ltd., London

Renzoni, A. (1963). Ricerche ecologiche ed idrobiologiche su Mytilus galloprovincialis Lam. nel Golfo di Napoli. Boll. Pesca Piscic. Idrobiol. 18: 187-238

Renzoni, A. (1980). Shellfish and heavy metals in the Mediterranean. Thalassia Jugosl. 16: 335-346

Schulz-Baldes, M. (1978). Lead transport in the common mussel Mytilus edulis. In: Mc Lusky, D. S., Berry, A. J. (eds.) Physiology and behaviour of marine organisms. Proc. 12th Eur. mar. Biol. Symp., Pergamon Press, New York, p. 211-218

Scott, D. M., Major, C. W. (1972). The effect of copper (II) on survival, respiration and heart rate in the common blue mussel Mytilus edulis. Biol. Bull. 143: 679-688

Sheppard, C. R. C., Bellamy, D. J. (1974). Pollution of Mediterranean around Naples. Mar. Pollut. Bull. 5: 42-44

Sternlieb. I., Goldfischer, S. (1976). Heavy metals and lysosomes. In: Dingle J. T., Dean, R. T. (eds.) Lysosomes in biology and pathology, Vol. 5. Elsevier, Amsterdam, p. $185-200$

Thompson, R. J., Ratcliffe, N. A., Bayne, B. L. (1974). Effects of starvation on structure and function in the digestive gland of the mussel (Mytilus edulis L.) ). J. mar biol. Ass. U.K. 54: $699-712$

Vega, M. M., Marigómez, J. A., Angulo, E. (1989). Quantitative alterations in the structure of the digestive cell of Littorina littorea on exposure to cadmium. Mar Biol. 103: 547-553

Viarengo, A. (1989). Heavy metals in marine invertebrates: mechanisms of regulation and toxicity at the cellular level. C.R.C. Crit. Rev. aquat. Sci. 1(2): 295-317

Viarengo, A., Canesi, L., Pertica, M., Poli, G., Moore, M. N., Orunesu, M. (1990). Heavy metal effects on lipid peroxidation in the tissues of Mytilus galloprovincialis Lam. Comp. Biochem. Physiol. 97C: 37-42

Viarengo, A., Moore, M. N., Mancinelli,G., Mazzucotelli, A., Pipe, R. K., Farrar, S. V (1987). Metallothioneins and lysosomes in metal toxicity and homeostasis in marine mussels: the effects of cadmium in the presence and absence of phenanthrene. Mar Biol. 94: 251-257

Widdows, J. (1978). Physiological indices of stress in Mytilus edulis. J. mar. biol. Ass. U.K. 58: 125-142

Widdows, J., Bayne, B. L., Donkin, P., Livingstone, D. R., Lowe, D. M., Moore, M. N., Salked, P. N. (1981). Measurement of the responses of mussels to environmental stress and pollution at Sullon Voe: a based-line study. Proc. R. Soc. Edinb. 80: 323-383

Manuscript first received: January 27, 1992

Revised version accepted: May 8, 1992 